\title{
Vertical Transmission of COVID-19 in Children of Sero-positive Mothers to SARS- CoV-2 in Southeast Mexico: A Case Report
}

\author{
Güneydoğu Meksika'da SARS-CoV-2 Seropozitif Annelerin Çocuklarında \\ COVID-19'un Vertikal Bulaşı: Bir Olgu Sunumu
}

Diego Lopez Salinas', Fabiola Barba Leon', Liliana Rodríguez García², Maria Valeria Jimenez-Baez², Federico Garma Montiel${ }^{4}$, Maria Eugenia Sanchez Castuera ${ }^{3}$

\section{Abstract}

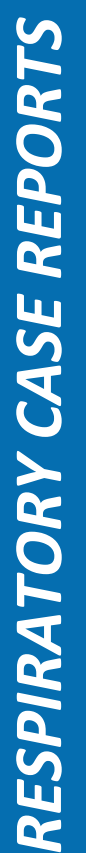

The clinical features of Covid-19 have been described in adults and infants younger than 1 year of age, although there is little data on the characteristics and the potential of intrauterine transmission in newborns. A case of infection was identified in a baby born in Cancún Quintana Roo, in a regional hospital at the beginning of the epidemic. The patient did not require intensive care, nor were there any serious complications. The mother was infected with SARSCoV-2, showing mild respiratory symptoms. Although 10 mothers with symptoms of SARS-CoV-2 have been observed to date, only one case of a positive newborn has been identified in the hospital. In summary, newborns are susceptible to SARS-CoV-2 infection. The SARS-CoV-2 PCR-positive newborn had no symptoms, and so SARS-Cov2 may be considered less severe in neonates than in adults. Vertical intrauterine transmission in women who develop COVID19 pneumonia is possible, although evidence is still lacking in Latin America and around the world.

Key words: SARS-CoV-2, Covid-19, pregnancy, newborn.

\section{Özet}

Yenidoğanlarda potansiyel intauterin bulaş ve özellikleri hakkında çok az veri olmasında karşın, COVID19'un klinik özellikleri, erişkinlerde ve bir yaşından küçük çocuklarda tanımlanmıştır. Epideminin başında Cancun Quintana Roo'da bölgesel bir hastanede yeni doğan bir bebekte enfeksiyon saptandı. Hastada ciddi bir komplikasyon yoktu ve yoğun bakım ihtiyacı da olmadı. SARS-Cov-2 ile enfekte olan anne hafif solunumsal semptomlar gösteriyordu. Bu tarihte SARS-CoV-2 semptomları olan 10 tane anne görülmesine rağmen, hastanede sadece bir yenidoğan pozitif olarak saptandı. Kısaca, yenidoğanlarda da SARS-CoV-2 enfeksiyonu düşünülmelidir. SARS-CoV2 PCR pozitif yenidoğanlarda semptom olmayabilir ve SARS-CoV-2'nin yenidoğanlarda erişkinlerden daha hafif seyrettiği düşünülebilir. Dünya'da ve Latin Amerika'da henüz bir kanıt olmamasına karşın, COVID pnömonisi gelişen bir kadında vertikal intrauterin bulaş mümkün olabilir.

Anahtar Sözcükler: SARS-CoV-2, Covid-19, Gebelik, yenidoğan.
'Mexican Institute Social Security, Quintana Roo, Medical Benefits Headquarters, Mexico

${ }^{2}$ Department of Gynecology, Mexican Institute Social Security, Hospital General Regional No. 17 Cancún Quintana Roo, Mexico

${ }^{3}$ Department of Pediatrics, Mexican Institute Social Security. Hospital General Regional No. 17 Cancún Quintana Roo, Mexico ${ }^{4}$ Department of Epidemiology, Mexican Institute Social Security. Hospital General Regional No. 17 Cancún Quintana Roo, Mexico
'Meksika Sosyal Güvenlik Enstitüsü, Quintana Roo, Tıbbi Yardımlar Genel Merkezi, Meksika

${ }^{2}$ Meksika Sosyal Güvenlik Enstitüsü, Hastane Genel Bölge No. 17 Cancún Quintana Roo, Kadın Hastalıkları Bölümü, Meksika

${ }^{3}$ Meksika Sosyal Güvenlik Enstitüsü Pediatri Bölümü. Hastane Genel Bölge No. 17 Cancún Quintana Roo, Pediatri Bölümü, Meksika

${ }^{4}$ Meksika Sosyal Güvenlik Enstitüsü. Hastane Genel Bölge No. 17 Cancún Quintana Roo, Epidemiyoloji Bölümü, Meksi$\mathrm{ka}$

Submitted (Başvuru tarihi): 22.07.2020 Accepted (Kabul tarihi): 10.1 1.2020

Correspondence (iletişim): Maria Valeria Jimenez-Baez, Department of Epidemiology, Mexican Institute Social Security. Hospital General Regional No. 17 Cancún Quintana Roo, Mexico e-mail: valeria.jimenezb@gmail.com 
Coronavirus disease (COVID-19), caused by SARS-CoV2, was first detected in Wuhan, China in December 2019 (1). After the disease spread exponentially around the world, an international public health emergency was declared by the World Health Organization (WHO) on January 30, 2020 (2). Mexico reported a total of 74,560 confirmed cases and 8,134 deaths on 05/26/2020 (3). SARS-CoV-2 is a member of the coronavirus family, subtype Beta-Coronavirus, with an RNA genome, that has been shown to share the Angiotensin-Converting Enzyme receptor with SARS-CoV-2 (4-7), which has a mortality rate of $10 \%$ in the general population and up to $25 \%$ in pregnant women $(5,6)$. To date, two forms of the virus have been identified: type L (accounting for $70 \%$ of cases) and type S (30\% of cases) (7).

The human transmission of SARS-CoV-2 occurs through fomites, direct contact or aerosols, resembling the spread pathways of influenza. An incubation period of 14 days has been reported, with an average of 5.2 days, and it has been shown that symptoms tend to develop an average of 2.5 days after exposure to the virus (7).

The most common manifestations of coronavirus 19 are fever, cough, fatigue, myalgia, cough with expectoration and headache, associated from abnormalities identified in the laboratory with the presence of lymphopenia, the elevation of liver enzymes, DHL, VSG, PCR, D-dimer and a prolongation of clotting times (7).

Coronavirus 19 has a high infectivity rate and develops easily in a susceptible population, and pregnant women and their newborns are included in this group (6-8). Due to the lack of records of confirmed cases in the previously mentioned population group, there is a lack of information regarding its management and the existence of vertical transmission, and so maternal-fetal complications prevail $(9,10)$. In Mexico, newborns with COVID-19 in the first 24 hours have not been reported.

We report here on a case of probable intrauterine vertical transmission involving a patient with COVID-19 infection.

\section{CASE}

We present here the case of a 28-year-old female hospital warehouse assistant with a history of hyperthyroidism under treatment with thiamazole, and with a penicillin allergy. $\mathrm{O}+$ blood type, G4A0C2P1 previous cesarean section 11 and 6 years ago due to cord to neck circulation and uncertain fetal status, Pl 9 years ago with death as a result.

Background of this pregnancy: I present six threats of abortion from the beginning of the pregnancy with treat- ment based on Indomethacin and Micronized progesterone. It carried on a preterm delivery at hospital in the 31 st week of gestation with intrahepatic cholestasis conditioning. The patient was treated with ursodeoxycholic acid and indomethacin in three doses, as well as a pulmonary maturation scheme with Dexamethasone 4 doses. Table 1 presents the analytical evolution of the patient, who experienced an increase in transaminase parameters during her stay, with a clinical diagnosis of cholestasis of pregnancy. The patient presented with fever, general discomfort, headache and a runny nose, and with a history of coming into contact with two co-workers who had tested positive for SARS CoV-2 PCR. The patient tested positive on 04/16/2020. Telephone follow-up begins with the results shown in Table 2. On April 28, she went again for presenting fetal hypomotility, having 34 SDG. It was decided to perform a cesarean section due to fetal hypomotility and the COVID-19 diagnosis, and a male child was born at 22:38 hours with APGAR 8/9, CAPUR$\mathrm{RO}$, after 37 weeks gestation, weighing 2,250 grams and $50 \mathrm{~cm}$ in height. The neonate was kept in joint accommodation, and received lactation via a mixed technique (mother with the use of an N95 face mask without valve), and remained afebrile and asymptomatic, without respiratory distress or any need for mechanical ventilation. A nasopharyngeal culture was taken at 24 hours and PCR was performed for COVID-19. The day after the pregnancy was resolved, the mother reported slight respiratory distress that she attributed to the use of N95 face mask, coupled with the presence of a decreased vesicular murmur in the right lung base. A chest $\mathrm{X}$-ray of the mother revealed a glass-like opacity (Figure 1). The maternal biochemical parameters are presented in Table 3. A change in transaminase levels was observed from those taken during previous hospitalizations. Arterial Blood Gas: $\mathrm{pH}:$ 7.48, $\mathrm{pO}_{2}: 149 \mathrm{mmHg}, \mathrm{pCO} 2: 21 \mathrm{mmHg}, \mathrm{HCO} 3$ : 15.6, $\mathrm{FiO}_{2}: 21 \%$. The patient's situation improved, and the newborn remained asymptomatic for the duration of hospitalization, with no evidence of respiratory distress, and they were discharged. On May 5, the newborn recorded a positive PCR, and the mother was notified by telephone to bring the newborn to respiratory triage for assessment. At 17 days of age (May 15, 2020), the newborn was called to undertake second PCR for COVID-19, which was negative. The mother has reported the newborn being asymptomatic since the last evaluation. After the sample was taken, a chest radiograph was requested that revealed no change (Figure 2). 
Table 1: Biochemical parameters during hospitalization

\begin{tabular}{|c|c|c|c|c|}
\hline Laboratory / Date & $02 / 04 / 20$ & $04 / 04 / 20$ & $05 / 04 / 20$ & $07 / 04 / 20$ \\
\hline Glucose & $71 \mathrm{mg} / \mathrm{dL}$ & $156 \mathrm{mg} / \mathrm{dL}$ & $68 \mathrm{mg} / \mathrm{dL}$ & $93 \mathrm{mg} / \mathrm{dL}$ \\
\hline Urea & $4 \mathrm{mg} / \mathrm{dL}$ & & $9 \mathrm{mg} / \mathrm{dL}$ & $6 \mathrm{mg} / \mathrm{dL}$ \\
\hline Creatinine & $0.3 \mathrm{mg} / \mathrm{dL}$ & & $0.3 \mathrm{mg} / \mathrm{dL}$ & $0.4 \mathrm{mg} / \mathrm{dL}$ \\
\hline Total bilirubin & $0.7 \mathrm{mg} / \mathrm{dL}$ & $0.5 \mathrm{mg} / \mathrm{dL}$ & & $0.5 \mathrm{mg} / \mathrm{dL}$ \\
\hline Direct bilirubin & $0.3 \mathrm{mg} / \mathrm{dL}$ & $0.2 \mathrm{mg} / \mathrm{dL}$ & & $0.2 \mathrm{mg} / \mathrm{dL}$ \\
\hline Indirect Bilirubin & $0.4 \mathrm{mg} / \mathrm{dL}$ & $0.3 \mathrm{mg} / \mathrm{dL}$ & & $0.3 \mathrm{mg} / \mathrm{dL}$ \\
\hline Albumin & $3.1 \mathrm{mg} / \mathrm{dL}$ & $2.9 \mathrm{mg} / \mathrm{dL}$ & & \\
\hline ALT & $50 \mathrm{UI} / \mathrm{L}$ & 99 UI/L & 93 UI/L & 83 UI/L \\
\hline AST & $37 \mathrm{UI} / \mathrm{L}$ & $76 \mathrm{UI} / \mathrm{L}$ & $68 \mathrm{UI} / \mathrm{L}$ & $53 \mathrm{UI} / \mathrm{L}$ \\
\hline $\mathrm{DHL}$ & $168 \mathrm{UI} / \mathrm{L}$ & $201 \mathrm{UI} / \mathrm{L}$ & $153 \mathrm{UI} / \mathrm{L}$ & \\
\hline FA & & $176 \mathrm{UI} / \mathrm{L}$ & & \\
\hline Hemoglobin & $12.40 \mathrm{~g} / \mathrm{dL}$ & & $10 \mathrm{~g} / \mathrm{dL}$ & $11 \mathrm{~g} / \mathrm{dL}$ \\
\hline Hematocrit & $36.2 \%$ & & $30.7 \%$ & $32.5 \%$ \\
\hline Platelets & $229103 \mu \mathrm{L}$ & & $228103 \mu \mathrm{L}$ & $222103 \mu \mathrm{L}$ \\
\hline White Blood Cells & $7.0103 \mu \mathrm{L}$ & & $8.8103 \mu \mathrm{L}$ & $4.7103 \mu \mathrm{L}$ \\
\hline Lymphocytes (\%) & $29103 \mu \mathrm{L}$ & & $37.2103 \mu \mathrm{L}$ & $18.6103 \mu \mathrm{L}$ \\
\hline TP & $11 \mathrm{seg}$ & & & \\
\hline TPT & $28.5 \mathrm{seg}$ & & & \\
\hline Fibrinogen Derived & $619 \mathrm{mg} / \mathrm{dL}$ & & & \\
\hline
\end{tabular}

\section{DISCUSSION}

In China, Zhang et al. (11) reported on four cases of COVID-19 positive newborns with a maternal history of SARS-CoV-2 (respiratory symptoms, chest CT with compatible findings and positive PCR test) during the third trimester of pregnancy. The neonates presented positive PCR tests, and three underwent chest CT scans with findings indicative of COVID-19. All received supportive treatment, and none required mechanical ventilation. This study supports the presence of vertical transmission by excluding infection by contamination, although there is a lack of sufficient evidence to confirm this.

Chen et al. (12) reported on nine pregnant women in the third trimester of pregnancy with a positive COVID-19 PCR test, with no comorbidities and with mild respiratory symptoms. Of the nine, eight had multiple ground-glass opacities on chest tomography; four developed perinatal complications related to the SARS-CoV-2 infection, including fetal distress and a premature rupture of the membranes. Nine infants were born through Cesarean section, with APGAR scores of 8-9 in the first minute and
9-10 in the fifth minute, and with no respiratory symptoms. Oropharyngeal samples were taken, and in six cases samples of cord blood, placenta, amniotic fluid and breast milk were collected, all of which were negative in a PCR test for COVID-19. This systematic review is similar to our case, given the inclusion of mothers with SARS-CoV-2 infection in the third trimester of pregnancy, but differs when negative PCR are presented.

In two case reports, one from China and the other from Spain, two newborns were confirmed with COVID-19. The first was to a 34-year-old woman at 40 weeks of gestation who was being treated for hypothyroidism, who presented with fever, lymphopenia, ground glass opacities in the upper and lower left lobes on a chest CT, and a positive nasopharyngeal exudate PCR for SARS-CoV-2 (13). This case resembles the case in the present study in terms of the hypothyroidism, which leads us to believe there may be some relationship between pregnant patients with hypothyroidism and susceptibility to COVID-19. 


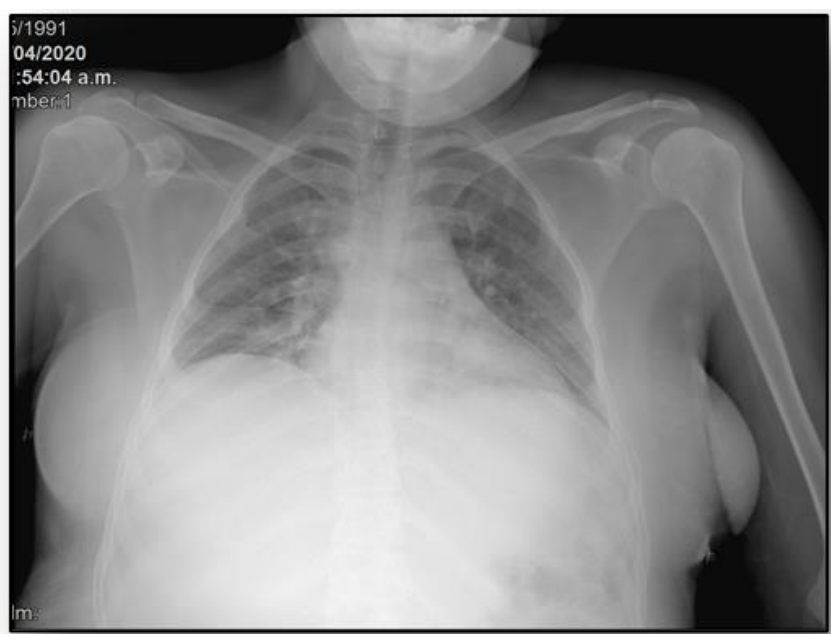

Figure 1: Thorax Tele. Without the presence of infiltrated in a polished glass

The case reported in Spain was a 41 -year-old woman with a 38-SDG pregnancy, a history of IVF and hypothyroidism under treatment. An urgent cesarean section was performed for pre-eclampsia, and the neonate was obtained with an APGAR score of $7 / 9$, beginning with respiratory distress that merited a nasal CPAP (withdrawn at 2 hours), transfer to the neonatal unit and subsequent referral to joint accommodation. Three days after hospitalization, the mother developed fever and respiratory symptoms compatible with COVID-19, and with a chest $\mathrm{X}$-ray suggestive of pneumonia. A nasopharyngeal exudate RT-PCR SARS-CoV-2 test was requested, which was positive. Later, the mother required admission to the intensive care unit, and the girl was separated from the mother. On the sixth day of life, a sample was taken from the neonate for COVID-19 testing, and was negative, but when repeated 8 days after birth, the test was positive. The girl presented with intermittent polypnea with lower chest retractions, while a chest radiograph showed ground glass opacity, predominantly in the right parahilar. After 24 hours the respiratory symptoms disappeared. On day 13 of life, the test for COVID-19 was still positive (14). This case, unlike ours, presented with respiratory symptoms after pregnancy resolution, which prevents the exclusion of the possibility of contamination of the neonate for positivity by COVID-19.

This case is relevant, as there are no previous records of newborns with positive PCR for SARS-CoV-2 at 24 hours of life, or maternal confirmations of COVID-19 by maternal antecedent PCR of COVID-19.

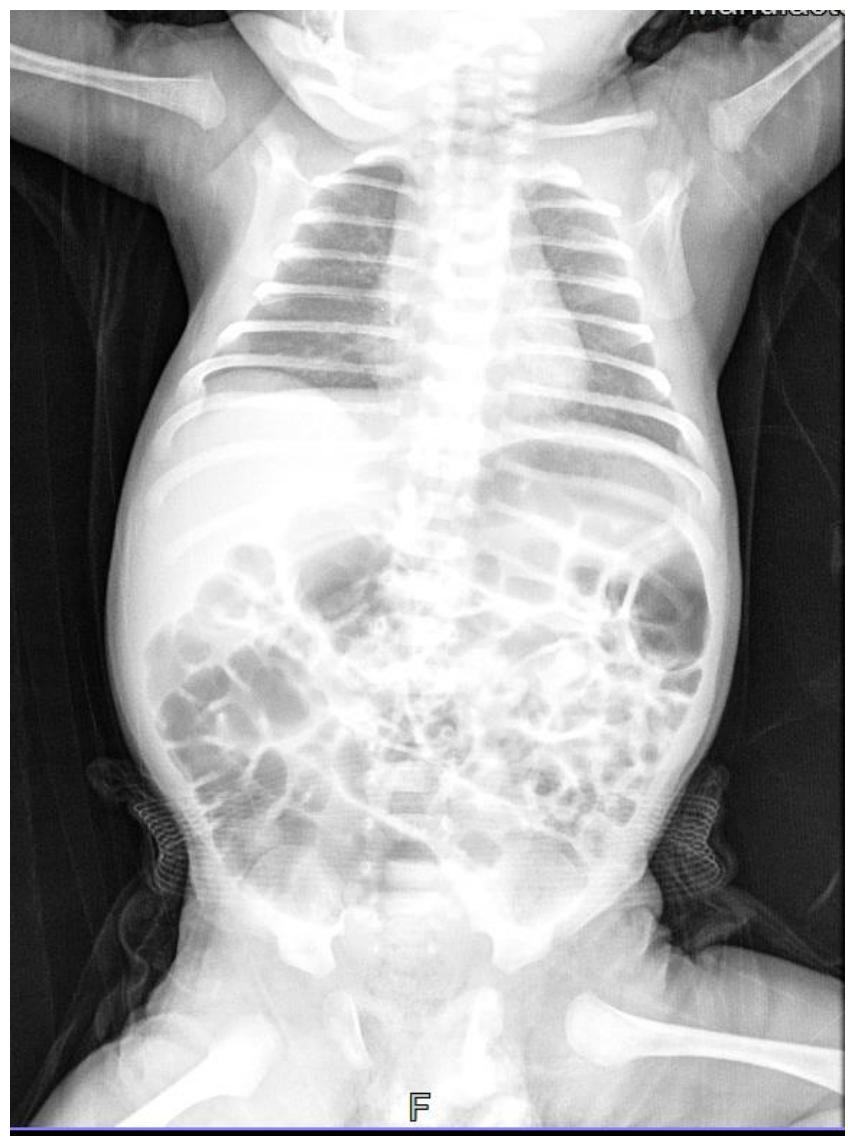

Figure 1: Tele thorax RN 17 days VEU. It is observed without radiographic changes that suggest COVID-19 infection

Although the patient was 18 days post onset of respiratory symptoms due to COVID-19 infection, she was managed as an at-risk patient, given previous reports of transmissibility of up to 45 days (15).

It is important to highlight the increase in transaminases in this case, considering that the patient had no typical clinical data indicating COVID-19 infection. She did, however, have an increase in transaminases, which leads us to believe that there may be a relationship between early modifications of liver markers and COVID-19 infection, which can be considered an early marker of infection. This assumption should be determined in all of pregnant patients with suspected COVID-19 infection, since it is considered a serious factor in patients positive for COVID-19 infections (16). 
Table 2: Home follow-up of the pregnant patient

\begin{tabular}{|l|l|l|l|l|l|l|l|l|l|l|l|l|l|}
\hline Odybophagia \\
\hline Asymptomatic
\end{tabular}

In the review by Zhang et al. (11) and the case report by Wang et al. (13), symptomatology in mothers begins two to three days before birth, and even after it, questioning whether the median incubation time is at 5.2 days, according to Li et al. (17). These data lead us to consider the possibility that the immunological state of pregnancy could produce a shortening of the median presentation of respiratory clinical data for SARS-CoV-2 infection in pregnant women, unlike in adults in the general population, by three days.

On the other hand, in our patient we could rule out the secretion contagion route, as the cesarean section was performed with all the required protective measures, the mother wore an N95 mouthpiece at all times and the sample was taken 24 hours after birth. Contrary to the case reported by Alonso et al. (14), in which a positive PCR was obtained at 8 days of life, with a negative result 6 days after birth, indicating horizontal transmission. This type of in utero infection has already been demonstrated in cases of viruses such as cytomegalovirus (18).

Viral load plays an important role at the time of detection of the virus by PCR, since in the first days of the incubation period it is low and may not be detected, being be- low the detection threshold (14). If our patient had been infected via horizontal transmission, it would have been assessed in the first hours of the incubation period, reducing the likelihood of viral detection in the nasopharyngeal exudate.

Due to the lack of information and studies on vertical transmission in COVID-19 positive mothers, it is not possible to completely determine its presence in this case. Making such a determination would require more specific tests, such as the presence of $\lg M$ in the blood, which was not taken in our patient. Accordingly, health systems must consider the IGM determination for SARS-CoV-2 within the study protocol package for such patients. No SARS-Cov-2 viral RNA tests of neonatal cord blood, placenta samples or amniotic fluid have been carried out to date. $\lg M$ and $\lg G$ in maternal and newborn blood have not been measured. The mother not used n95 mask with valve, and it was believed that the virus in the expiratory air mixed with the external environment and infected the baby. This is the first case of vertical transmission to be reported in Mexico, and strongly supports this theory, and so this study can be considered as the basis for the development of future research. 
Table 3: Newborn Biochemical Parameters

\begin{tabular}{|c|c|c|}
\hline Laboratory / Date & $28 / 04 / 20$ & $29 / 04 / 20$ \\
\hline Glucose & $134 \mathrm{mg} / \mathrm{dL}$ & \\
\hline Urea & $11 \mathrm{mg} / \mathrm{dL}$ & \\
\hline Creatinine & $0.3 \mathrm{mg} / \mathrm{dL}$ & \\
\hline Total bilirubin & $0.4 \mathrm{mg} / \mathrm{dL}$ & $0.5 \mathrm{mg} / \mathrm{dL}$ \\
\hline Direct bilirubin & $0.2 \mathrm{mg} / \mathrm{dL}$ & $0.2 \mathrm{mg} / \mathrm{dL}$ \\
\hline Indirect Bilirubin & $0.2 \mathrm{mg} / \mathrm{dL}$ & $0.3 \mathrm{mg} / \mathrm{dL}$ \\
\hline \multicolumn{3}{|l|}{ Albumin } \\
\hline ALT & $21 \mathrm{UI} / \mathrm{L}$ & $16 \mathrm{UI} / \mathrm{L}$ \\
\hline AST & $18 \mathrm{UI} / \mathrm{L}$ & $21 \mathrm{UI} / \mathrm{L}$ \\
\hline $\mathrm{DHL}$ & 227U/L & $237 \mathrm{U} / \mathrm{L}$ \\
\hline $\mathrm{FA}$ & 234 UI/L & 183 UI/L \\
\hline Hemoglobin & $11.5 \mathrm{~g} / \mathrm{dL}$ & $9.5 \mathrm{~g} / \mathrm{dL}$ \\
\hline Hematocrit & $34.3 \%$ & $28.1 \%$ \\
\hline Platelets & $187103 \mu \mathrm{L}$ & $158103 \mu \mathrm{L}$ \\
\hline White Blood Cells & $9.0103 \mu$ & $12.6103 \mu \mathrm{L}$ \\
\hline Lymphocytes (\%) & $19.2103 \mu$ & $13.2103 \mu \mathrm{L}$ \\
\hline TP & $10.5 \mathrm{seg}$ & $10.6 \mathrm{seg}$ \\
\hline TPT & $25.6 \mathrm{seg}$ & $27.3 \mathrm{seg}$ \\
\hline Fibrinogen Derived & & $701 \mathrm{mg} / \mathrm{dL}$ \\
\hline PCR & $1.87 \mathrm{mg} / \mathrm{dL}$ & \\
\hline DIMER-D & $274 \mathrm{ng} / \mathrm{mL}$ & $319 \mathrm{ng} / \mathrm{mL}$ \\
\hline
\end{tabular}

There are still unresolved questions regarding infections in newborns, there is an infection in utero, there is vertical transmission, there is a longer period of transmission in pregnant women, there is a shorter period until the presentation of respiratory symptoms in pregnant women than in the general population, there are changes in the liver associated with the presentation of severity in pregnant women.

\section{ACKNOWLEDGEMENT}

Severe COVID-19 infection proceeds rapidly, according to the clinical finding and chest CT findings, although no effective drug has yet been identified. In such situations, the use of glucocorticosteroids may be clinically useful. The number of patients continues to increase worldwide, while data on the treatment and prognosis of the disease are still insufficient. Further research is warranted in the future.

\section{CONFLICTS OF INTEREST}

None declared.

\section{AUTHOR CONTRIBUTIONS}

Concept - D.L.S., F.B.L., L.R.G., M.V.J.B., F.G.M., M.E.S.C.; Planning and Design - D.L.S., F.B.L., L.R.G., M.V.J.B., F.G.M., M.E.S.C.; Supervision - D.L.S., F.B.L., L.R.G., M.V.J.B., F.G.M., M.E.S.C.; Funding -; Materials -; Data Collection and/or Processing - M.V.J.B., F.G.M.; Analysis and/or Interpretation - M.V.J.B., F.B.L.; Literature Review - M.V.J.B., D.L.S., L.R.G.; Writing - M.V.J.B., F.B.L.; Critical Review - M.V.J.B., L.R.G., D.L.S.

\section{YAZAR KATKILARI}

Fikir - D.L.S., F.B.L., L.R.G., M.V.J.B., F.G.M., M.E.S.C.; Tasarım ve Dizayn - D.L.S., F.B.L., L.R.G., M.V.J.B., F.G.M., M.E.S.C.; Denetleme - D.L.S., F.B.L., L.R.G., M.V.J.B., F.G.M., M.E.S.C.; Kaynaklar -; Malzemeler -; Veri Toplama ve/veya İşleme - M.V.J.B., F.G.M.; Analiz ve/veya Yorum - M.V.J.B., F.B.L.; Literatür Taraması M.V.J.B., D.L.S., L.R.G.; Yazıyı Yazan - M.V.J.B., F.B.L.; Eleştirel İnceleme - M.V.J.B., L.R.G., D.L.S.

\section{REFERENCES}

1. Zhu N, Zhang D, Wang W, Li X, Yang B, Song J, et al. A novel coronavirus from patients with pneumonia in China, 2019. N Engl J Med 2020; 382:727-33. [CrossRef]

2. Declaración del Director General de la OMS sobre la reunión del Comité de Emergencia del Reglamento Sanitario Internacional acerca del nuevo coronavirus (2019nCoV) [Internet]. Who.int. 2020 [cited 14 May 2020]. Available from: https://www.who.int/es/dg/speeches/detail/who-directorgeneral-s-statement-on-ihr-emergency-committee-onnovel-coronavirus-(2019-ncov).

3. Información Internacional y Nacional sobre Nuevo Coronavirus con corte al 26 mayo 2020 en la Página de internet de la Subsecretaria de prevención y Promoción de la

Salud.

https://www.gob.mx/cms/uploads/attachment/file/5541

31/Comunicado_Tecnico_Diario_COVID-

19_2020.05.26.pdf.

4. Lu Q, Shi Y. Coronavirus disease (COVID-19) and neonate: What neonatologist need to know. J Med Virol 2020; 92:564-7. [CrossRef]

5. Chen D, Yang H, Cao Y, Cheng W, Duan T, Fan C, et al. Expert consensus for managing pregnant women and neonates born to mothers with suspected or confirmed 
novel coronavirus (COVID - 19) infection. Int J Gynaecol Obstet 2020; 149:130-6. [CrossRef]

6. Rothana H, Byrareddy S. The epidemiology and pathogenesis of coronavirus disease (COVID-19) outbreak. J Autoimmun 2020; 109:102433. [CrossRef]

7. Coronavirus disease 2019 (COVID-19): Epidemiology, Virology, Clinical features, Diagnosis, and Prevention, UpToDate, April 2020 https://www.uptodate.com/contents/coronavirus-disease2019-covid-19-epidemiology-virology-clinical-featuresdiagnosis-and-prevention/print.

8. Wang L, Shi Y, Xiao T, Fu J, Feng X, Mu D, et al. Chinese expert consensus on the perinatal and neonatal management for the prevention and control of the 2019 novel coronavirus infection (First edition). Ann Transl Med 2020; 8:4. [CrossRef]

9. Fan C, Lei D, Fang C, Li C, Wang M, Liu Y, et al. Perinatal Transmission of COVID-19 Associated SARS-CoV-2: Should We Worry?. Clin Infect Dis 2020:ciaa226. (in press). [CrossRef]

10. De Rose D, Piersigilli F, Ronchetti M, Santisi A, Bersani I, Dotta A, et al. Novel Coronavirus disease (COVID-19) in newborns and infants: what we know so far. Ital J Pediatr 2020; 46:56. [CrossRef]

11. Zhang $Z, Y \cup X, F \cup T$, Liu $Y$, Jiang $Y$, Yang B, et al. Novel coronavirus infection in newborn babies under 28 days in China. Eur Respir J 2020; 55:2000697. [CrossRef]

12. Chen H, Guo J, Wang C, Luo F, Yu X, Zhang W, et al. Clinical characteristics and intrauterine vertical transmis- sion potential of COVID-19 infection in nine pregnant women: a retrospective review of medical records. Lancet 2020; 395:809-15. [CrossRef]

13. Wang S, Guo L, Chen L, Liu W, Cao Y, Zhang J, et al. A case report of neonatal 2019 coronavirus disease in China. Clin Infec Dis 2020; 71:853-7. [CrossRef]

14. Alonso Díaz C, López Maestro M, Moral Pumarega M, Flores Antón B, Pallás Alonso C. Primer caso de infección neonatal por SARS-CoV-2 en España. An Pediatr (Barc) 2020; 92:237-8. [CrossRef]

15. Guo L, Ren L, Yang S, Xiao M, Chang D, Yang F, et al. Profiling early humoral response to diagnosis novel coronavirus disease (COVID-19). Clin Infect Dis 2020; 71:778-85. [CrossRef]

16. Ministerio de Sanidad. Manejo de la Mujer embarazada y del recien nacido con COVID-19 versión del 17 de Marzo del 2020. https://www.mscbs.gob.es/profesionales/saludPublica/cc ayes/alertasActual/nCov-

China/documentos/Documento manejo embarazo recien nacido.pdf

17. Li Q, Guan X, Wu P, Wang X, Zhou L, Tong Y, et al. Early transmission dynamics in Wuhan, China, of novel coronavirus-infected pneumonia. N Engl J Med 2020; 382:1 199-207. [CrossRef]

18. Wujcicka W, Wilczyński J, Nowakowska D. Alterations in TLRs as new molecular markers of congenital infections with Human cytomegalovirus?, Pathog Dis. 2014 Feb;70(1):3-16. [CrossRef] 